Dept. of Zoology,

Fac. of Science, Zagazig University

\title{
LIGHT, ULTRASTGRUCTURE AND CYTOCHEMICAL STUDIES ON MYXOBOLUS SP. (MYXOZOA: MYXOBOLIDAE) INFECTING THE GILL TISSUE OF THE NILE FISH LABEO NILOTICUS AT ASSIUT LOCALITY EGYPT. \\ (With One Table and 12 Figures)
}

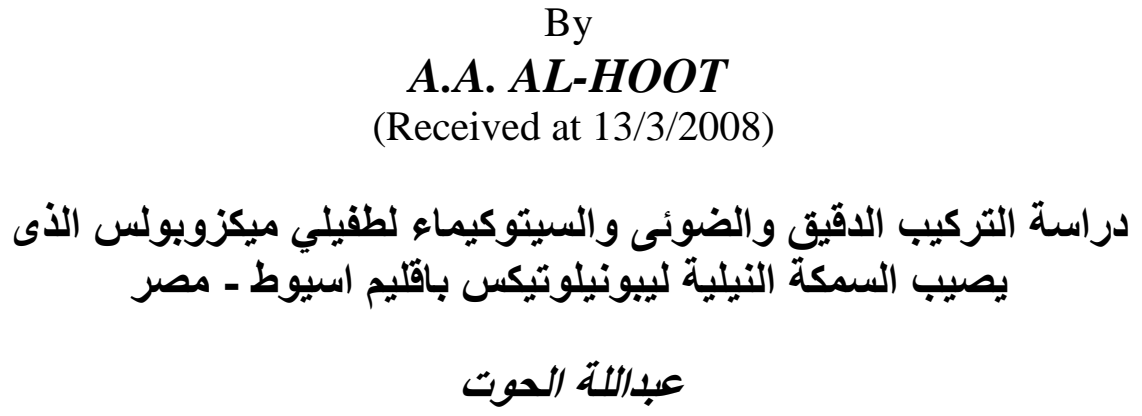

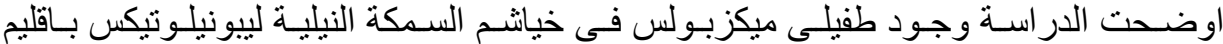

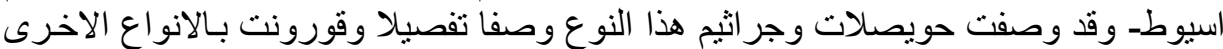

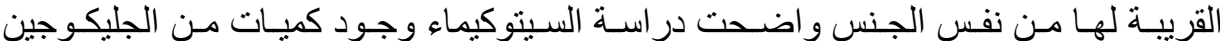

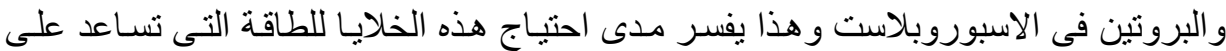

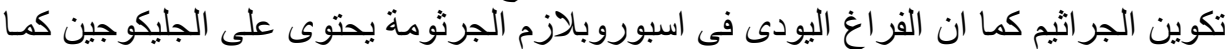

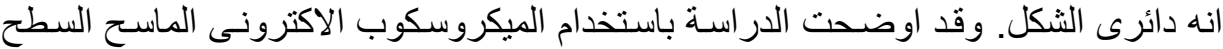

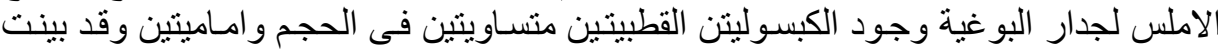

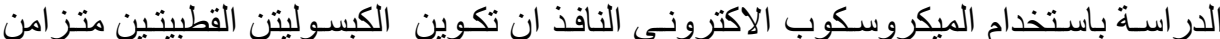

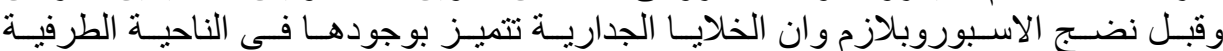
والاسبوروبلازم يتميز بتجمع مو اد الجليكوجين والخيبان الحبيات الكثيفة الكترونيا

\section{SUMMARY}

Myxobolus sp. (Myxozoa: Myxosporea) was recovered from gill tissues of the Nile fish Labeo niloticus at Assiut locality, Egypt. Mature spores were elliptical in shape, with two equal polar capsules situated anteriorly and occupied nearly more than half length of the spores. Each spore measured 10.4-14.0 $\mu \mathrm{m}$ in length and 8.0-11.3 $\mu \mathrm{m}$ in width. Polar capsules were $5.5-7.3 \mu \mathrm{m}$ in length and 3.5-4.5 $\mu \mathrm{m}$ in width. They 
occupied nearly more than half length of spores. Semi-thin-sections revealed that the plasmodium was surrounded by an outer wall of the host origin and inner wall of the parasite and contained numerous spores at different stages of development. Cytochemical studies showed that the spores and sporoblasts contained large amount of glycogen and protein. Best's carmine stain showed the presence of iodinophilous vacuoles in the sporoplasm of spores as a rounded structure. Scanning electron microscope revealed the smooth nature of the spore valve surface. The polar capsules, shell valves and sutural ridge line are represented by anterior and posterior grooves. The transmission electron microscope revealed that the mature spores have two valves arising from the valvogenic cells and joined by the sutural line.

Key words: Myxosporea, Myxobolus sp. and Labeo niloticus

\section{INTRODUCTION}

Myxosporea are mainly parasites of fish. The myxosporean Myxobolus sp. is a common parasite infecting a wide variety of organs and tissues in many families of fishes. Infection may cause serious disease and high mortality among fishes (Molnar, 1982; Lom, 1984, Cone \& Wiles, 1985, Stehr \& Whitaker, 1986 and El-Matbouli et al., 1992). Today Myxobolus sp. have special attention than before, since they may infect man through consumption of under cooked infected fishes (Boreham et al., 1998). Myxobolus sp. have been decribed from fishes by many authors such as (Walliker, 1969; Fahmy et al., 1971, 1975; Kent \& Hoffmann, 1984; Abed, 1987 and Ali et al., 2002).

The ultrastructure of Myxobolus sp. has been studied by many authors such as (Lom \& de Puytorac, 1965; Current, 1979; Mitchell et al., 1985; Pulsford \& Mathews, 1982; El-Matbouli et al., 1990; Kent et al., 1993 and Abed, 1999; 2005). However, for the best of the author,s knowledge, no further details on this species have so far been reported.

The present work was desined to study the light microscopy, ultrastructure and cytochemistry of Myxobolus sp. infecting the gill tissues of the Nile fish Labeo niloticus at Assiut locality 


\section{MATERIALS and METHODS}

Forty adult fish Labeo niloticus were collected during summer, 2006 from the main River Nile at Assiut, Upper Egypt. The collected fish ranged from $30-50 \mathrm{~cm}$. in length and were examined for myxosporean parasites. The irregular shape of polysporic and histozoic plasmodia were observed macroscopically. They were found in gill tissues of fishes and processed as follows:

For light microscopy: Wet mounts were prepared and examined, others were dried and stained with Giemsa stain. Lugol's iodine solution was added to the wet mounts to observe the presence of iodinophilous vacuoles in the sporoplasm. The polar filaments were readily extruded in wet mounts by addition of $5 \% \mathrm{KOH}$. and photographed for measurement and description purposes. Other plasmodia were fixed in formol alcohol, then embedded in paraffin wax as usual. Paraffin sections were stained with certain histochemical reagents (periodic acid Schiff's reagents (P.A.S.), P.A.S. reactions with diastase control, Bests carmine, and Bromophenol blue stains).

For scanning electron microscopy (SEM); pieces of the parasitized fish containing plasmodia, were fixed in a solution of $5 \%$ glutaraldehyde at $\mathrm{pH} 7.4$ for 3-4 hr., washed in Na-phosphate buffer (pH 7.4), following maceration using needles to release spores and allowed to settle into coated cover slips. Dehydration of samples were carried out by ascending grades of ethanol series then processed in a critical point drying apparatus. The cover slips were subsequently mounted on copper studs, gold coated, and examined using scanning electron microscope (J. EOL JSM-5400LV).

For transmission electron microscopy (TEM); plasmodia were fixed in phosphate-buffered 5\% glutaraldehyde ( $\mathrm{pH} \mathrm{7.4)} \mathrm{for} \mathrm{3-4} \mathrm{hr.,}$ post-fixed in $1 \%$ (osmium tetroxide) for $2 \mathrm{hr}$., washed in the same buffer, dehydrated in ascending grades of ethanol series and finally embedded in Epon. Ultra-thin sections were contrasted with urinyl acetate and lead citrate to be examined with a transmission electron microscope (Jeol CXII) at $80 \mathrm{Kv}$.

\section{RESULTS}

Out of the surveyed forty fishes Labeo niloticus eight (20\%) showed parasitic infection of gill tissue. Varied sized yellowish white cystic structure, elongated to oval in shape, were found embedded in the 
gill tissues. Cysts were attached firmly to the primary gill lamellae. The larger parasitic cysts measured $(1.3-6 \times 0.4-0.8 \mathrm{~mm})$, while the smaller ones measured $(0.4-1.0 \times 0.3-0.5 \mathrm{~mm})$ and were found attached to the secondary gill lamellae. The branchial arch was free from parasitic infection. The infected gill tissues were pale.

Wet mounts (imprints) prepared from the infected gill tissues revealed the presence of numerous elliptical shaped spores. They were blunt with slightly narrow anterior end and slightly broad posterior one, ovoid shaped in front view and spindle-shaped in sutural view and lateral view (Fig. 1). They measured 10.4-14 $\mu \mathrm{m}$ x $8.0-11.3 \mu \mathrm{m}$. Two equal oval to pyriform polar capsules converging anteriorly (Fig. 2), each measured, $5.5-7.3 \times 3.5-4.5 \mu \mathrm{m}$. The ratio of polar capsules to spore length equals 0.52 . The polar filament measured $25-40 \mu \mathrm{m}$ in length when it is fully extruded, but when it is resting inside the polar capsule, it consists of 5-6 coils.

When Lugol's iodine was added, a brownish rounded to elliptical mass was detected within the sporoplasm of the spore, commonly known as iodinophilous vacuole, measuring 2.9-3.2 $\mu \mathrm{m}$ and corresponds to a vacuole observed in stained specimen. The sporoplasm is finely granulated with two nuclei (Fig. 2) each measuring, 1.1-1.9 $\mu \mathrm{m}$.

\section{Histological findings:}

Varied sized parasitic cysts were recognized, attached to the primary gill lamellae of all infected fishes. The cyst wall was partially built-up of the host tissue and separated by a narrow space from the subjacent plasmodium membrane (Fig. 3). Within the plasmodia vegetative forms, developing sporonts, sporoblasts, maturing and mature spores were found. The mature parasitic spores tended to locate toward the plasmodial center (Fig. 4).

Periodic acid Schiff's (P.A.S.) stained sections showed that the cyst wall, was P.A.S. positive. The sporoblasts and iodinophilous vacuole within the sporoplasm of spores were deep red in colour P.A.S. positive (Fig. 5). Some sections were exposed to diastase to be digested for 30-60 minutes at $37^{\circ} \mathrm{C}$ followed by P.A.S. stain, the result was that the outer layer of the cyst wall became negative, except the mucous peripheral cells which remain positive. The sporoblasts and iodinophile vacuole changed their red colour as a result of digestion of the glycogen present in these structure (Fig. 6).

Best's carmine stained sections revealed that the sporoblasts and the iodinophilous vacuole of spores stained deep red in colour (Fig. 7). 
Bromophenal blue stained sections showed that the sporoblasts and spores stained blue in colour (Fig. 8).

\section{Scanning electron microscopy:}

Frontal view of the scanned spores of this species revealed the smooth nature of both spore valves and inconspicuous suture separating them. The two anteriorly situated polar capsules were distinct (Fig. 9). The valve had parallel striations. Some variations in the pattern were evident, each striation did not extend over the entire length of the spore and was observed to be cross-linked or branched (Figs. 9, 10). The anterior polar capsules, shell valves and sutural ridge, represented by anterior and posterior grooves were also evident

\section{Transmission electron microscopy:}

Ultra-thin sections prepared from the parasitic cysts revealed obviously the attachement of the plasmodial membrane to the cyst wall. The host cells contributed apparently in the formation of the cyst wall. Sporoblasts, developing sporonts were located at the periphery of plasmodium, while maturing spores were located toward the plasmodium center (Figs. 3, 4).

Electron micrographs showing the spore developmental stages (stages of sporogenesis) gave an evidence that the development of two spore polar capsules was synchronized and consisted of an electrondense outer zone, two adjacent translucent zones and cortex containing polar filaments. Polar filaments in the early developing polar capsules (primordial filaments) were loosely coiled. The nearly mature spores revealed the presence of two distinct polar capsules (with more synchronization of development) containing regularly peripherally arranged filament coils (Fig. 11). The well-developed mature polar capsules possessed enlarged 5-6 polar filaments coiled in a dense granular matrix and arranged perpendicular to the length of the mature capsule. The mature spores have two valves arising from the valvogenic cells and joined by the sutural line (Fig. 12). The valvogenic cells revealed an accumulation of electron-dense bodies "valve-forming material" especially in regions of sutural ridge. The sporoplasmic cells were ensheathed by valvogenic cells and consisted of pairs of cells. By time they became fashioned together. The cytoplasm contained light and dark electron dense-bodies, the sporoplasm filled all the space beneath polar capsules and partially extended between them. 
Table 1: Comparison between the present parasite and other related species of myxosporean, Myxobolus spp.

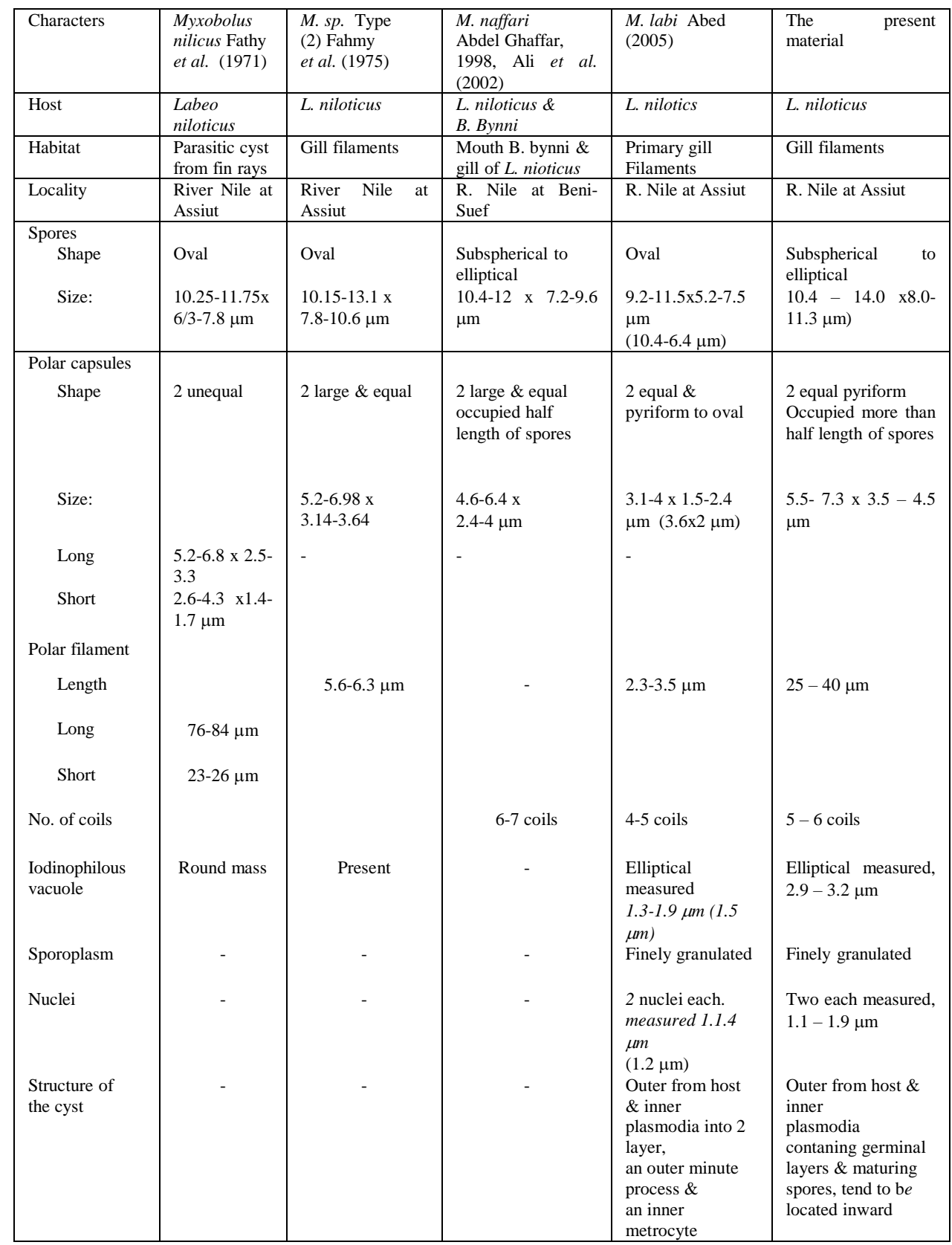


Assiut Vet. Med. J. Vol. 54 No. 117 April 2008 
Assiut Vet. Med. J. Vol. 54 No. 117 April 2008 
Assiut Vet. Med. J. Vol. 54 No. 117 April 2008 


\section{FIGURE LEGNES}

Fig. 1: Photomicrograph showing fresh smears of Myxobolus sp. The spore is elliptical in shape in ventral view (arrow) and spindle-shaped in lateral view (asterisk *). X 1000.

Fig. 2: Photomicrograph showing spores of Myxobolus sp, They are elliptical in shape with two equal polar capsules located anteriorly (arrow heads). The sporoblasm is finely granulated with two smaller nuclei (arrow) and contains elliptical shaped iodinophilous vacuoles (asterisk *). X 1000.

Fig. 3: Photomicrograph showing a large pseudocyst enclosing a plasmodium $(\mathrm{P})$ which contains numerous spores at different stages of development. The plasmodium ectoplasm is impacted with germinal layers (asterisk). The developing and maturing spores tend to locate toward the plasmodium center Toluidine blue stain. X 200.

Fig. 4: Photomicrograph showing higher magnification of the pseudocyst center. The numerous spores (arrow), have spindle-shaped in lateral view, and ovoid shaped in ventral view Toluidine blue stain. X 1000.

Fig. 5: Photomicrograph showing T.S. of the cyst. Parasitic germinal layer (nucleated layer containing sporoblasts) stained red in colour and the iodinophilous vacuoles in sporoplasm of spores stained deep red (arrow head). P.A.S. stain X 400.

Fig. 6: Photomicrograph showing the iodinophilous vacuole $(*)$ of Myxobolus sp. after digestion with diastase. X 400.

Fig. 7: Photomicrograph showing the rounded structure of iodinophilous vacuole (*) of Myxobolus sp. stained with Best's carmine stain. X 400.

Fig. 8: Photomicrograph showing spores of Myxobolus sp. stained with Bromophenol blue stain. X 400.

Fig. 9: Scanning electron micrograph showing spore of Myxobolus sp. with two anteriorly polar capsules $(*)$, smooth shell valves (arrow). X. 7500

Fig. 10: Frontal view of a spore showing inconspicuous sutural ridge and smooth valves. The valve striation do not extend over the entire length of spore $(*)$ scanning electron micrograph. X 7500 . 
Fig. 11: Developing spores of $M$. sp, the spore shows synchronous development of polar capsules. The polar capsule exhibits two electron layers. The polar filaments (*) within the polar capsules are loosely coiled. The valve forming material (vm) in valvogenic cells. Transmission electron micrograph. $\mathrm{X} 6700$.

Fig. 12: A mature spore showing two valves (arrows) arised from the two valvogenic cells and joined by a sutural line. Note the accumulation of valve-forming material (*) in the cytoplasm of valvogenic cell. Transmission electron micrograph. X 8000 .

\section{DISCUSSION}

Since the spores of the present studied parasite possess two anteriorly situated polar capsules and the sporoplasm contains an iodinophilous vacuole, the parasites belong to family Myxobolidae Thelohan, 1892 and genus Myxobolus Bütschli, 1882.

The macroscopic observation of the parasitic cysts were similar to those described in previous studies on myxosporean parasites (Fahmy et al., 1971, 1975 and Abed, 2005).

Gill parasitic myxosporeans, including Myxobolus sp. were commonly described in gill filaments of infected fishes (Waliker, 1969; Lom \& Molnar, 1983, Fahmy et al., 1971, 1975; Kent \& Hoffmann, 1984; Rocha et al., 1992; Azevedo \& Matos, 1996; Ali et al., 2002 and Abed 2005).

When the present species is compared in details with the previously described species such as Myxobolus niloticus described by Fahmy et al. (1971), Myxobolus sp. type (2) described by Fahmy et al. (1975), Myxobolus naffari described by Ali et al. (2002) and Myxobolus labi described by Abed (2005), it was found to be more or less similar to Myxobolus naffari described by Ali et al. (2002), although the above mentioned study had not presented a detailed microscopic study of that species Table (1). The present study is the first to describe in detail a Myxobolus naffari species infecting the gills of the Nile fish Labeo niloticus.

The presence of large amount of carbohydrates and protein in the germinal layer (nucleated layer containing sporoblasts) may explain the function of these cells, since they are highly specialized, thus they need more energy to produce offsprings in the form of spores. 
In the present study, the presence of a red rounded structure in the sporoplasm of spores as shown by Best's carmine stain, may indicate that this structure is a store house for glycogen which may be used as a source of energy for establishment and further development of the parasite.

The plasmodial wall was delimited by a membrane similar to Myxobolus sp. described by Desser \& Paterson (1978).

In the present study the elliptical shape of the spores, smooth valve surface, slit like opening and suture lines were similar to those described by Desser \& Paterson (1978), Mitchell et al. (1985), El-Mathouli et al. (1990) and Dzulinsky et al. (1994).

The sequence of events responsible for development of polar capsules in the present study were identical to those reported for several species of Myxosporea (Lom \& de Puytorac, 1965; Current et al., 1979 and Abed 2005).

The gradual reduction of valvogenic cells till they were completed in mature spores and the formation of sutures joined the valves was similar to that reported in other myxosporeans sp. (Desser \& Paterson, 1978; Desser et al., 1983 a, b; Abdel-Ghaffar et al., 2004 and Abed (2005).

The accumulation of electron-dense bodies especially in regions of sutural ridge, appeared to share in the process of forming the outer shell of the spore.

The binucleated sporoplasm of the present species was similar to the most myxosporean species, (Current et al., 1979; Desser et al., 1983 a, b and Abed, 2005).

The electron dense inclusions in the sporoplasm of the present species were similar to that described in most myxosporean spp. (El-Matbouli et al., 1990).

\section{ACKNOWLEDGEMENTS}

It is a pleasure to express my cordial thanks to prof. Dr. G.H. Abed professor of Parasitology, Faculty of Science, Assiut University for helping me and revising the manuscript. 


\section{REFERENCES}

Abdel-Ghaffar, F.; Abdel-Baki, A. and El-Garhy, M. (2004): Ultrastructural characteristic of the sporogenesis of genus Myxobolus infecting some Nile fishes in Egypt. Parasitol. Res., 125, 1-8.

Abed, G.H. (1987): Studies on Myxosporidia of some Nile fishes in Assiut Province, A.R. Egypt. M.Sc. Thesis, Assiut University, Assiut, Egypt

Abed, G.H. (1999): Scanning and transmission electron microscopic studies on Myxobolus niloticus infecting the fish Labeo niloticus at Assiut, Upper Egypt. J. Egypt. Ger. Soc. Zool., 28: $13-22$.

Abed, G.H. (2005): Light and electron microscopic studies of Myxobolus labi n.sp. (Myxozoa: Myxobolidae) infecting the gill tissue of the River Nile fish Labeo niloticus at Assiut, Upper Egypt. J. Egypt. Ger. Soc. Zool., 48: 229-244.

Ali, M.A.; Al-Raheid, K.A.; Sakran, T.; Abdel-Baki, A.A. and AbdelGhaffar, F. (2002): Some species of the genus Myxobolus (Myxozoa, Myxosporea) infecting freshwater fish of the River Nile, Egypt, and the impact on their hosts. Parasitol, Res., 88: 9-15.

Azevedo, C. \& Matos, E. (1996): Henneguya malabarica sp. now. (Myxozoa, Myxobolidae) in the Amazonian fish Hoplias malabaricus. Parasitol, Res., 82, 222-224.

Boreham, R.E.; Hedrick, S.; O’Donghue, P.J. and Stenzel, D.J. (1998): Incidental finding of Myxobolus spores (Protozoa: Myxozoa) in stool samples from patients with gastrointestinal symptoms. J. Clin. Microbiol., 36 (12): 3728-3730.

Cone, D.K., and Wiles, M. (1985): Trophozoite morphology and development site of two species of Myxobolus (Myxozoa) parasitizing Catostomus commersoni and Notismigonus crysoleucas in Atlantic Canada. Can. J. Zool., 63: 2919-2923.

Current, W.L. (1979): Henneguya adipose (Myxosporida) in the channel catfish: ultrastructure of the plasmodium wall and sporogenesis. J. Protozool., 26: 209-217.

Current, W.L.; Janovy, T. and Knight, S.A. (1979): Myxosoma funduli Kudo (Myxosporidia) in Fundulus kansae, Ultrastructure of the Plasmodium wall and sprogenesis. J. Protozool., 26: 574583. 
Desser, S.S. and Paterson, B. (1978): Ultrastructural and cytochemical observations on sporogenesis of Myxobolus sp. (Myxosporidia: Myxobolidae) from the common shiner Notropis cornulus. J. Protozool., 25: 314-326.

Desser, S.S. Molnar, K. and Horvath, I. (1983a): An ultrastructural study of the myxosporeans Sphaerospora angulata and Sphaerospora carassic in the common carp, Cyprinus carpio L. J. Protozool., 30: 415-422.

Desser, S.S., Molnar, K. and Weller, I. (1983b): Ultrastructure of sporogenesis of Thelohanellus nikolski Akhmerov, 1955 (Myxozoa: Myxosporea) from the common carp, Cyprinus carpio. J. Parasitol., 69: 504-518.

Dzulinksy, K., Cone, D.K. Faulkner, G.T. and Cusack, R. (1994): Development of Myxobolus neurophilus (Guilford, 1963) (Myxosporea) in the brain of yellow perch (Perca flavescens) in vinegar Lake, Nova Scotia. Cand. J. Zool., 72: 1180-1185.

El-Matbouli, M.; Fischerscheri, Th. and Hoffmann, R.W. (1992): Present knowledge of the life cycle, taxonomy, Pathology and therapy of some Myxosporea important for freshwater fish. Ann. Rev. Fish Dis., 2: 367-402.

El-Matbouli, M.; Pischer, Scherl, T. and Hoffman, R.W. (1990): Light and electron microscopic studies on Myxobolus cotti ElMatbouli and Hoffmann, 1987 infecting the central nervous system of the bullhead (Cottus gobio). Parasitol. Res., 76: 219-227.

Fahmy, M.A.; Mandour, A.M. and El-Naffar, M.K. (1971): Myxobolus niloticus in the fish Labeo niloticus from the River Nile of Assiut. J. Egypt. Soc. Parasitol., 1: 39-46.

Fahmy, M.A.; Mandour, A.M. and El-Naffar, M.K. (1975): A survey of Myxosporidia of freshwater fishes collected from the River Nile of Assiut province. J. Egypt. Soc. Parasitol., 485: 93102.

Kent, M.L. and Hoffmann, G.L. (1984): Two new species of Myxozoa, Myxobolus inacquus sp. $\mathrm{n}$. and Henneguya theca sp. Riculidae from the brain of a South American Knife fish, Eigemannia virescens (V.). J. Protozool., 31: 91-94. 
Kent, M.; Whitaker, D.J. and Margolis, L. (1993): Transmission of Myxobolus articus Pugachev and khokhlov, 1979, a myxosporean parasite of Pacific salmon, via a triactinomyxon from the aquatic oligochaete Stylodrilus heringianus (Lumbriculidae). Can. J. Zool., 71: 1207 - 1211.

Lom, J. and Molnar, K. (1983): Myxobolus basilamellaris sp. n. (Myxozoa: Myxosporea), a parasite of the gills of common carp (Cyprinus carpio L.). Folia Parasitol, 30: 1-3.

Lom, J. (1984): Diseases caused by Protistans. In: Kinne, O. (Ed.) Diseases of marine animals, Vol. IV. Part I. Biologische Anstalt Helgoland, Hamburg, P. 114-168.

Lom, J. and De Puytorac, P. (1965): Studies on the myxosporidian structure and polar capsule development. Protistol., 1: 53-65.

Mitchell, L.G. Seymour, C.L. and Gamble, J.M. (1985): Light and electron microscopy of Myxobolus hendricksoni sp. nov (Myxozoa: Myxobolidae) infecting the brain of the fathead minnow, Pimephales promelas Rafinewque. J. fish. Dis., 8: 75-89.

Molnar, K. (1982): Biology and histopathology of Thelohanellus nikolskii Achmerov, 1955 (Myxosporea, Myxozoa) a protozoan parasite of the common carp (Cyprinus carpio). Z. Parasitenkd, 68: 269-277.

Pulsford, A. and Mathews, R.A. (1982): An ultrastructural study of Myxobolus exiguous Thélohan, 1895 (Myxosporea) from grey mullet Cremimugil lobrosus (Risso). J. Fish. Dis., 5: 509-562.

Rocha, E; Matos, E. and Azevedo, C. (1992): Henneguya amazonica n.sp. (Myxozoa, Myxobolidae), Parasitizing the gills of Crenicichla lepidota Heckel, 1840 (Teleostei, Ciclidae) from Amazon River. Europ. J. Protistol., 28: 273-278.

Stehr, C. and Whitaker, D.J. (1986): Host-parasite interaction of the myxospreans Kudoa paniformis Kabata \& Whitaker, 1981 and Kudoa thyrsitis (Gilehrist, 1924) in the muscle of pacific whiting, Merluccius productus (Ayres): an ultrastructure study. J. Fish Dis., 9: 505-517.

Waliker, D. (1969): Myxosporidea of some Brazilian freshwater fishes. J. Parasitol., 55: 942-948. 